\title{
ANALISIS KUALITATIF FORMALIN PADA IKAN ASIN YANG BEREDAR DI KOTA MAKASSAR
}

\author{
Rahmawati $^{\mathbf{1}}$ \\ 1) Akademi Analis Kesehatan Muhammadiyah Makassar \\ Alamat Korespondensi: rahmawatiamma60@gmail.com
}

\begin{abstract}
Abstrak
Penilitian ini dilatarbelakangi oleh penggunaan formalin yang digunakan sebagai bahan pengawet yang disalahgunakan sebagai Bahan Tambahan Makanan (BTM). Tujuan penelitian ini untuk mengetahui adanya zat formalin pada ikan asin yang beredar di Kota Makassar. Teknik pengambilan sampel adalah Random Sampling dimana sampel pemeriksaan dalam penelitian ini sebanyak 10 sampel. Analisis kualitatif formalin pada ikan asin dilakukan menggunakan metode fenilhidrazin yaitu hasil destilasi direaksikan dengan fenilhidrazin $1 \%, \mathrm{~K}_{3}\left(\mathrm{Fe}(\mathrm{CN})_{6}\right) 1 \%$, dan $\mathrm{HCl}$ pekat, adanya formalin ditandai dengan adanya perubahan warna menjadi merah. Hasil analisis kualitatif formalin pada ikan asin yang beredar di Kota Makassar didapatkan 10\% sampel positif dari 10 sampel yang dianalisis mengandung formalin.

Kata kunci: formalin, ikan asin
\end{abstract}

\section{PENDAHULUAN}

Ikan merupakan bahan pangan yang mudah rusak (membusuk). Hanya dalam waktu sekitar 8 jam sejak ikan ditangkap sudah dapat menimbulkan proses perubahan yang mengarah pada kerusakan. Oleh karena itu agar ikan dan hasil perikanan lainnya dapat dimanfaatkan semaksimal mungkin, perlu di jaga kondisinya. Pengolahan merupakan salah satu cara untuk mempertahankan ikan dari proses pembusukan, sehingga mampu di simpan lama sampai tiba waktunya untuk di jadikan bahan konsumsi. Salah satu caranya adalah pembuatan ikan asin (Adawyah, 2011).

Jenis-jenis ikan yang banyak diolah menjadi ikan asin terutama adalah ikan teri, ikan tembang, ikan pepetek, ikan kembung, ikan manyung, ikan lemuru, ikan layang dan tongkol. Ciri-ciri ikan asin yang bagus adalah warna dagingnya mendekati warna asli ikan segar, tidak berbau asam atau tengik, tidak terdapat bercak noda, dan tidak lembek berair atau kaku (Muchtadi, 2013).

Pemakaian bahan pengawet dari satu sisi menguntungan karena dengan bahan pengawet, bahan pangan dapat dibebaskan dari kehidupan mikroba. Namun disisi lain, bahan pengawet pada dasarnya adalah senyawa kimia yang merupakan bahan asing yang masuk bersama bahan pangan yang dikonsumsi. Apabila pemakaian bahan pangan dosisnya tidak teratur dan tidak diawasi, kemungkinan besar akan menimbulkan kerugian pada pemakainya baik bersifat langsung maupun tidak langsung (Cahyadi, 2009).

Formalin merupakan bahan beracun dan berbahaya bagi kesehatan manusia. Formalin dapat bereaksi cepat secara kimia di dalam sel sehingga menekan fungsi sel dan menyebabkan kematian sel yang menyebabkan keracunan pada tubuh dengan gejala sebagai berikut: sukar menelan, alergi, sakit kepala, mual, sakit perut yang akan akut disertai muntahmuntah, mencret darah, timbulnya depresi susunan syaraf, gangguan peredaran darah, dan dapat menyebabkan kanker (Alsuhendra, 2013).

Pada penelitian kali ini peneliti mencurigai adanya zat formalin pada produk ikan asin yang diperjual-belikan melihat banyak keganjalan ketika melihat tekstur,warna, bau dan keawetannya.

\section{METODE PENELITIAN}

\section{Alat dan Bahan}

Alat yang digunakan dalam penelitian ini adalah alat destilasi, batang pengaduk, cawan petri, erlenmeyer, labu iod, corong gelas, lumpang, pipet volum,

Jurnal Medika: Media Ilmiah Analis Kesehatan Volume 1 No. 2, Desember 2016 ISSN: 2540-7910 42 
rak tabung dan tabung reaksi, sendok tanduk, dan timbangan.

Bahan penelitian yang digunakan adalah ikan asin, asam klorida $(\mathrm{HCl})$ pekat, asam fosfat $\left(\mathrm{H}_{3} \mathrm{PO}_{4}\right)$ pekat, $\mathrm{K}_{3}\left(\mathrm{Fe}(\mathrm{CN})_{6}\right) 1 \%$, fenhylhydrazin $1 \%$, aquadest.

\section{Prosedur Penelitian \\ Pesiapan sampel}

Ikan asin kering ditimbang sebanyak 50 gram, ditambahkan dengan $100 \mathrm{ml}$ aquadest. Dihomogenkan kemudian ditambahkan dengan $\mathrm{H}_{3} \mathrm{PO}_{4}$ pekat sebanyak $20 \mathrm{ml}$ dan dimasukkan kedalam labu iod kemudian didestilasi. Destilasi dilakukan sampai di dapat hasil destilasi $50 \mathrm{ml}$ yang di tampung dalam erlenmeyer.

\section{Pembuatan \\ Larutan \\ Kalium \\ Ferrisianida $\mathrm{K}_{3}\left(\mathrm{Fe}(\mathrm{CN})_{6}\right)$}

Larutkan 1 gr $\left.\mathrm{K}_{3} \mathrm{Fe}(\mathrm{CN})_{6}\right)$ dengan $100 \mathrm{ml}$ air suling di dalam $100 \mathrm{ml} \mathrm{labu}$ ukur sampai tanda batas,. simpan dalam botol, larutan ini stabil selama 1 minggu pada suhu $4^{\circ} \mathrm{C}$.

\section{Pembuatan Larutan Fenilhidrazin}

Larutkan 1 gr fenilhidrazin hidroklorida pekat dalam $100 \mathrm{ml}$ aquadest menggunakan gelas ukur.

\section{Pemeriksaan kualitatif pada sampel}

Hasil destilat dipipet sebanyak 10 ml kemudian di tambahkan fenhylhydrazin $1 \%$ sebanyak $2 \mathrm{ml}$, ditambahkan $\mathrm{K}_{3}\left(\mathrm{Fe}(\mathrm{CN})_{6}\right) 1 \%$ sebanyak $1 \mathrm{ml}$ dan $\mathrm{HCl}$ pekat $5 \mathrm{ml}$. Dihomogenkan, kemudian diamati perubahan warna yang terjadi yaitu warna merah.

\section{Interpretasi Hasil}

Positif (+) : terjadi perubahan warna merah

Negatif (-) : tidak terjadi perubahan

\section{HASIL DAN PEMBAHASAN}

Berdasarkan penelitian pada tanggal 13 Mei sampai 14 Mei 2015 di Balai Basar Laboratorium Kesehatan tentang analisis kualitatif formalin pada ikan asin yang beredar di kota Makassar, didapatkan hasil sebagai berikut :
Tabel 1. Hasil Penelitian Analisis Kualitatif Formalin Pada Ikan Asin yang Beredar di Kota Makassar

\begin{tabular}{|c|c|c|c|}
\hline No & $\begin{array}{c}\text { Kode } \\
\text { Sampel }\end{array}$ & Sampel & Hasil \\
\hline 1 & A & Supermarket & + \\
\hline 2 & B & Supermarket & - \\
\hline 3 & $\mathrm{C}$ & $\begin{array}{l}\text { Pasar Pa'baeng- } \\
\text { baeng }\end{array}$ & - \\
\hline 4 & $\mathrm{D}$ & $\begin{array}{c}\text { Pasar Pa'baeng- } \\
\text { baeng }\end{array}$ & - \\
\hline 5 & $\mathrm{E}$ & Pasar Labuang Baji & - \\
\hline 6 & $\mathrm{~F}$ & Pasar Labuang Baji & - \\
\hline 7 & G & $\begin{array}{c}\text { Pasar Ratulangi } \\
\text { Lor.1 }\end{array}$ & - \\
\hline 8 & $\mathrm{H}$ & $\begin{array}{c}\text { Pasar Ratulangi } \\
\text { Lor.1 }\end{array}$ & - \\
\hline 9 & I & Pasar Terong & - \\
\hline 10 & $\mathrm{~J}$ & Pasar Terong & - \\
\hline
\end{tabular}

Tabel 2. Persentase Hasil Penelitian Analisis Kualitatif Formalin Pada Ikan Asin yang Beredar di Kota Makassar

\begin{tabular}{cc}
\hline Hasil Pemeriksaan & Jumlah (\%) \\
\hline Positif & 10 \\
Negatif & 90 \\
\hline Jumlah & $\mathbf{1 0 0}$ \\
\hline
\end{tabular}

Analisis kualitatif formalin pada ikan asin yang dilakukan pada 10 sampel yang di ambil dari 4 pasar tradisional dan 1 supermaket. Pemeriksaan bahan pengawet formalin sebanyak 10 sampel yang terlebih dahulu didestilasi dengan menambakan aquades dan $\mathrm{H}_{3} \mathrm{PO}_{4}$ pekat menghasilkan warna bening, hasil destilasi berupa larutan sampel. Larutan hasil destilasi kemudian di analisis secara kualitatif dengan menggunakan Fenilhidrazin $1 \%$ yang berwarna kuning, $\begin{array}{lll}\text { kemudian ditambahkan } \mathrm{K}_{3}\left(\mathrm{Fe}(\mathrm{CN})_{6}\right. & 1 \%\end{array}$ akan membentuk warna kuning setelah itu ditambahkan dengan $\mathrm{HCl}$ pekat. adanya formalin pada sampel ditandai dengan timbulnya warna merah pada larutan sampel.

Hasil analisis kualitatif formalin yang dilakukan pada 10 sampel ikan asin yang berasal beberapa pasar tradisional dan supermaket didapatkan $10 \%$ sampel mengandung formalin. Hal ini dibuktikan dengan timbulnya warna merah pada larutan sampel, sedangkan sampel yang lain negatif yaitu warna kuning. 
Formalin pada makanan sangat dilarang penggunaannya. Formalin dapat memberikan dampak akut dan kronis bagi kesehatan manusia, makanan yang mengandung formalin dalam kadar serandah apapun akan berdampak berbahaya terhadap kesehatan. Formalin masuk ke dalam tubuh secara rutin dan terus-menerusakan mengakibatkan penumpukan formalin dalam tubuh. penumpukan ini antara lain dapat menyebabkan kelainan pada hati, ginjal, jantung, dan otak, serta mengakibatkan kegiatan sel berhenti. Sedangkan konsumsi formalin dalam dosis tinggi dapat menyebabkan kejang-kejang, kencing, dan muntah darah yang mengakibatkan kematian. Secara umum dampak penggunaan formalin pada manusia dapat menurunkan derajat kesehatan dan kemampuan daya tahan tubuh manusia.

\section{KESIMPULAN}

Berdasarkan hasil penelitian yang dilakukan dapat disimpulkan bahwa analisis kualitatif formalin pada ikan asin yang beredar di kota Makassar di dapatkan 10\% sampel mengandung bahan pengawet formalin.

\section{DAFTAR PUSTAKA}

Adawyah, R. 2011. Pengolahan Dan Pengawetan Ikan. Jakarta: PT Bumu Aksara.

Adiwisastra, 1992. Keracunan, Sumber Bahaya, Serta Penanggulangannya. Bandung: Angkasa.

Alsuhendra, Ridawati, 2013. Bahan Toksi dalam Makanan. Bandung: PT Remaja Rosdakarya.

Anonim, 2014. Ikan Asin. Available from: wikipedia.org/wiki/ikan_asin.

Anonim, 2013. Ikan Asin, Dari (http://eprints.ung.ac.id/4156/20131-54244-632409061-bab2-

$\frac{15072013124714 . p d f}{16 / 04 / 2014}$ Diakses

Buckle, et.al. 2010. Ilmu Pangan. Jakarta: Universitas Indonesia.

Jangga, M. 2013. Penuntun Praktikum Toksikologi. Makassar: Akademi Analis Kesehatan Muhammadiyah Makasar.
Muchtadi, D. 2013. Prinsip Teknologi Pangan Sumber Protein. Bandung: Alfabeta.

Muchtadi, T. 2010. Teknologi Proses Pengolahan Pangan. Bandung: Alfabeta.

Winarno, F.G, 1997. Kimia Pangan dan Gizi. Jakarta: PT Gramedia Pustaka Utama.

Yuliarti, N. 2007. Awas Bahaya Dibalik Lezatnya Makanan. Yogyakarta: Andi. 